\title{
First-Time Registration of Ownership of Land Obtained Through Sale and Purchase under the Hand Whose Proof of Ownership Is Lost
}

\author{
Bintang Uswatun Hasanah; Any Suryani; Widodo Dwi Putro \\ Postgraduate program Legal Study and Notaries, Mataram University, Indonesia
}

http://dx.doi.org/10.18415/ijmmu.v6i2.754

\begin{abstract}
In practice, people who experience loss of proof of ownership rights over land where in the land title application must provide evidence of information about the land which includes data on physical and physical data. As stipulated in Law No. 5/1960 concerning Regulation on Basic Agrarian Principles article 19 that To ensure legal certainty by the Government registration of land throughout the territory of the Republic of Indonesia according to the provisions regulated by Government Regulations, registration includes one of giving letters - proof of rights, which applies as a strong evidence tool. The problem in this study is how is the validity of buying and selling rights to land carried out under the hands? and how is the registration process the first application for ownership of land to land whose proof of ownership is lost? The purpose of this study was to determine the validity of the sale and purchase of land rights carried out under the hand, and to find out the process of registering the transfer of land rights at the Bima City Land Office whose proof of ownership was lost. This research has benefits both academically and practically. The research used in this study is Empirical Law research and the approach in this study is the Legislative, Conceptual, and Sociological approaches. The process of buying and selling land under the hands carried out before the Head of Village / Lurah and witnesses is valid because the buying and selling conditions have been fulfilled according to Law Number 5 Year 1960 concerning Agrarian Principal Regulations. The first application for land registration in Bima City whose proof of ownership is lost in practice can still be registered.
\end{abstract}

Keywords: First Time Registration; Buying and Selling Under the Hand; Proof of Ownership Lost

\section{Introduction}

The rapid development that has been and is being actively implemented by the government in the economic and industrial fields cannot be separated from the need for land. Therefore, naturally in this period of development the role of land from time to time is increasingly important.

One of the objectives of the Agrarian Basic Law (UUPA) is to provide legal certainty relating to land rights held by the community.

Law No. 5/1960 concerning Regulation on Basic Agrarian Principles article 19 that To ensure legal certainty by the Government, registration of land throughout the territory of the Republic of 
Indonesia is carried out according to provisions regulated by Government Regulations. proof of rights, which applies as a strong evidence tool.

Land registration according to Government Regulation Number 24 of 1997 Article 1 paragraph (1) that land registration is a series of activities carried out by the Government continuously, continuously and regularly, covering the collection, processing, bookkeeping and presentation and maintenance of physical data and juridical data, in the form of maps and lists, concerning plots of land and units of flats, including the provision of letters of proof of their rights to plots of land which already have their rights and ownership rights to the apartment unit and certain rights that burden them.

Since the enactment of Law Number 5 of 1960 concerning Basic Agrarian Principles (UUPA), the transfer of land rights can be done through buying and selling which is intended to transfer ownership rights. What is meant by the transfer of land rights is a legal act of transferring land rights that is done intentionally so that the rights are released from the original holder and become the rights of other parties.

Land rights are the rights of a person or business entity to a plot of land and what is on it (buildings or plants), which is evidenced by evidence of ownership rights in the form of a certificate. Land rights, in ethical studies, are included in the legal rights section. This legal right comes from laws, legal regulations or other documents. Therefore, we can say land rights as legal rights as rights that are based on legal principles.

In fact, in the practice of buying and selling land rights that have not been certified are land that has not been registered at all at the Land Office. The practice of buying and selling is mostly done under the hands. So that in carrying out legal actions the sale and purchase of land rights is often not registered as mandated in the provisions of Article 19 paragraph (1) UUPA, because in its implementation, there are still many public who do not yet know and understand the importance of land registration.

Land that has not been certified can cause conflict and dispute. Most of the land that has not been certified as proof of ownership is girik or pethok. This condition can make it difficult for the community to conduct land tenure certification, namely on the evidence and the truth of the land deed.

People who want to immediately register their land so that they can obtain a certificate to guarantee legal certainty over the land, there are those who have lost proof of proof of valid rights as strong evidence, lack of public awareness of the importance of proof of rights. loss of proof of ownership, while in applying for property rights on land the owner of the rights must attach proof of information regarding his land which includes data on jurisis and physical data.

The formulation of the problem in this study are: 1) What is the validity of the sale and purchase of land rights under the hands? 2) How is the registration process for the first time an application for ownership rights to land that has proof of ownership lost?

The purpose of this study was to determine the validity of the sale and purchase of land rights carried out under the hand, and to find out the process of registering the transfer of land rights at the Bima City Land Office whose proof of ownership was lost.

The research used in this study is Empirical Law research and the approach in this study is the Legislative, Conceptual, and Sociological approaches.

\section{Result and Discussion}

\section{Validity of Land Rights Sale and Purchase Under the Hand}

\section{a. Buy and Sell Land in the City of Bima}

The sale and purchase of land should use an authentic deed that has been signed by an authorized official or Land Deed Officer, but in practice in the City of Bima there are still many implementation of buying and selling land that has not been registered that is carried out under the deed, deed made not in front of an authorized official or PPAT. And this is what has become a controversy in various circles 
because the buying and selling of land with a deed under the hand is still questionable by the majority of the community.

Many factors cause people to still use buying and selling under their hands. The reason they prefer buying and selling is because buying and selling under the hands is fairly fast or does not take a long time, besides buying and selling under the hands also does not require a lot of money, and buying and selling under the hands is easier.

But now there are many people in the city of Bima who understand the law, especially in land law, this is due to the many problems that often occur regarding land. So that it is rarely found again the people of Bima City who are buying and selling under the hand or buying and selling that is not done before the authorized official.

\section{b. Transition of Land Rights Due to Sale and Purchase of Unregistered Land}

The transfer of rights to land and / or buildings are: buying and selling, swapping, agreements to transfer rights, release of rights, surrender of rights, auctions, grants or other means agreed with other parties besides the Government for the implementation of development including public interest development that is not require special requirements.

It is affirmed in the provisions of Article 23 of the BAL, which states that such property rights must also be registered according to the provisions referred to in Article 19. Such registration is a strong evidentiary instrument regarding the abolition of ownership rights, as well as the legal transition and imposition of said rights.

It can be concluded that the purpose of the land registration is so that the actual landowner will get a land certificate with his name listed in the certificate as proof of land ownership. The land registration process applies to land that has neither been registered nor registered. With the issuance of the land certificate, one can avoid the possibility of a dispute regarding land ownership.

The Regulation of the Minister of Agrarian Affairs / head of the National Land Agency Number 3 of 1997 concerning Implementation Provisions of Government Regulation Number 24 of 1997 concerning Land Registration has not yet regulated in detail and / or specifically related to the transfer of land rights due to sale and purchase of land that has not been registered. However, in the provisions governing the registration of the transfer of rights due to the transfer of rights as stipulated in Article 103 up to Article 106, only Article 103 paragraph (3) and Article 106 discuss the matter of transferring land rights that have not been registered, and both Articles are still generally regulates the transfer of rights to land that have not been registered.

Related to the transfer of land rights due to buying and selling of land that has not been registered or in other words land that is not certified in the provisions of Government Regulation Number 24 of 1997 concerning Land Registration, no article specifically regulates the transfer of land rights specifically to land not yet registered. But from the provisions of the transfer of land rights from Article 37 to Article 40 of Government Regulation Number 24 of 1997 concerning Land Registration, which only in Article 39 paragraph (1) letter b pertains to land parcels that have not been registered, but in the provisions of Article 39 Paragraph (1) letter b only regulates the refusal by the Land Deed Managing Officer (PPAT) in terms of making a deed, which confirms that when it comes to land parcels that have not been registered, to him it is not conveyed:

1) Proof of rights as referred to in Article 24 paragraph (1) or a statement from the Head of Village / Urban Village stating that the person in question controls the parcel as referred to in Arti cle 24 paragraph (2); and 
2) A statement stating that the land in question has not been certified from the Land Office, or for land located in an area far from the position of the Land Office, from the right holder concerned to be strengthened by the Village / Village Head. ${ }^{1}$

In Article 37 of Government Regulation Number 24 of 1997 concerning Land Registration that the transfer of land rights through sale and purchase can only be registered, if proven by the deed made by the authorized PPAT according to the provisions of the applicable legislation. Because the deed made by PPAT is the basis and / or the basis of the right to make an application for registration of transfer of land rights.

\section{c. Legal Effects Caused by Sale and Purchase of Land Rights Against Land Not Registered in the City of Bima}

In every legal action carried out by a legal subject, of course it will lead to a legal consequence. The legal consequences of buying and selling land that has not yet been certified are in the form of submission of buying and selling objects, namely in the form of land to the buyer and submission of payment of the sale price to the seller.

The legal actions carried out in the City of Bima, namely the sale and purchase of land under the hands, resulted in legal consequences that could not be registered to transfer rights or referred to as the names mandated in the provisions of Law Number 5 of 1960 concerning Article 19 of the Agrarian Principles.

Based on the results of research in the field and interviews with Mr. Zaidun, he said, the legitimate sale and purchase of land without involving Land Deed Makers (PPAT) is legal, but the weakness of such legal actions cannot be registered with the National Land Agency office to change ownership data or transfer of title.

Can be concluded in terms of legal actions namely buying and selling land that is carried out under the hand creates legal consequences that is, there is no transfer of land and / or illegitimate rights transfer of land rights and the absence of legal certainty as well legal protection.

\section{d. Legal Protection Against Buyers of Land Rights Because of Buying and Selling of Unregistered Land}

In order to guarantee the legal protection by the state to the people, it is stated in the provisions of Article 28 D paragraph (1) of the 1945 Constitution that: Everyone has the right to the recognition, guarantee, protection and fair legal certainty and equal treatment before the law."

The philosophical foundation of the establishment of the LoGA is to realize legal certainty, order and legal protection with the essence of truth and justice. The form of guarantee of legal protection to the community in terms of obtaining land due to legal actions, namely buying and selling is carried out by the government and land registration in all areas of the Republic of Indonesia is carried out according to government regulations, as mandated in Article 19 of the BAL.

In the implementation of land registration, legal protection given to those who carry out legal acts based on the data presented depends on the publication system used in the implementation of land registration. The land registration publication system is divided into two parts, namely the positive publication system and the negative publication system. ${ }^{2}$

\footnotetext{
${ }^{1}$ Baiq Henni Paramita Rosandi, Akibat Hukum Jual Beli Hak Atas Tanah Yang Belum Didaftarkan, Universitas Mataram, 2016.

${ }^{2}$ Aartje Tehupeiory, Pentingnya Pendaftaran Tanah Di Indonesia, Raih Asa Sukses Penebar Swadaya Group, Jakarta, 2012, p. 26.
} 
According to Aartje Tehupeiory, basically there are two systems of publications known in land registration, namely: ${ }^{3}$

1) Positive publication system, a land certificate granted is valid as proof of absolute land rights and is the only proof of land. Provide absolute protection, both to the rights holders and to third parties because the information stated in the proof of rights cannot be changed. The results of this registration provide an instrument of proof that is absolute in nature and cannot be contested. If there is a mistake, even if there is a judge's decision, the information in the proof of the right remains irreversible. The government is responsible for the wrongdoing of its officers, so that the aggrieved party will receive compensation from the government for a number of land prices. Thus, people who were entitled to be eligible.

2) Negative publication system, legitimate legal action determines the transfer of rights to the buyer, and only gives rights protection to the right holder (the right), so that the publication system is known as the Nemo Plus Yuris principle, which is a principle that states that someone cannot sell buy if he is not authorized for the land in question. That a person who cannot act beyond the authority that is in his possession, whose name is stated in the proof of that right, is the rightful holder. Other people may believe, may not believe in the information that exists. If there is an error in the recording, based on the judge's decision can be corrected by the official who registers the land. Thus people who are entitled to remain protected.

The land registration system in Indonesia does not use a pure negative system in which the state does not guarantee the correctness of the data presented in the proof of rights, but uses negative negative positive tendencies. That is, even though the state does not guarantee the absolute correctness of the data presented in the proof of rights, the evidence of that right is categorized as evidence of legitimate and strong rights, as long as there is no court ruling which states otherwise. ${ }^{4}$

Based on the theory of legal protection according to Philipus M. Hadjon, legal protection means that legal provisions can be presented as an effort to prevent violations of law. This effort is implemented by establishing normative legal rules Reprensive legal protection aims to resolve disputes, including handling them in the judiciary.

The buyer of land rights because of the sale and purchase of land that has not been registered where the legal action is carried out in good faith by fulfilling the bright conditions and cash, thus the buyer gets recognition from the community concerned as the new owner and will get legal protection if later lawsuit against him from parties who consider the sale and purchase invalid.

\section{e. Validity in Land Buying Practices under the Hand}

The legal terms of the agreement can be found in the provisions of Article 1320 of the Civil Code which states that: for the validity of agreements, four conditions are needed:

1) Deal. What is meant by the agreement is the agreement of the parties that bind themselves, meaning that both parties in an agreement must have a free will to bind themselves, and that will must be stated explicitly or in silence. Thus an agreement is invalid if it is made or based on coercion, fraud or oversight. ${ }^{5}$

\footnotetext{
${ }^{3}$ Ibid, p. 27-29

${ }^{4}$ Penelitian Socio Legal, Perlindungan Hukum Bagi Pembeli Yang Beritikad Baik Dalam Pluralisme Jual Beli Tanah, p.5, acces May 2, 2019.

${ }^{5}$ R.Soeroso, Perjanjian Dibawah Tangan Pedoman Praktis Pembuatan Dan Aplikasi Hukum, Jakarta, Sinar Grafika, 2011, p.12.
} 
2) The ability to make an engagement. In general, people are said to be capable of carrying out legal actions if they are 21 years old and not under guardianship. ${ }^{6}$

3) A certain thing. According to the Civil Code certain things are:

a) A certain thing that is promised in an agreement is a matter or an item that is clear enough or certain that is at least determined by its type (Article 1332 of the Civil Code).

b) Only goods that can be traded can be the subject of an agreement (Article 1332 of the Civil Code).

4) A reason that is lawful. Although anyone can make any agreement, but there are exceptions, that is, an agreement must not conflict with the law, general provisions, morals, and decency (Article 1335 of the Civil Code). ${ }^{7}$

The validity of land sale and purchase if viewed from the Law or Government Regulations, the sale and purchase of land that is deemed legal, namely buying and selling land is carried out in the presence of a land deed maker or sale and purchase with an authentic deed authorized by an authorized official. This is in accordance with PP No.24 of 1997 concerning Land Registration in Article 37 point 1 which states that the transfer of rights to land and ownership rights to apartment units through buying and selling, exchange, grant income in the company and other legal deeds. Unless the transfer of rights through an auction can only be registered if proven by a deed made by the authorized PPAT according to the provisions of the applicable legislation. Therefore, the public should buy and sell with an authentic deed or deed approved by an authorized official so that the sale and purchase is carried out legally.

The Bima community includes people who still use the applicable Customary Law rules. The legal requirement for buying and selling rights to land according to customary law is the fulfillment of three elements, namely bright, cash and real. under the hand is a land sale and purchase agreement in Customary Law where the legal actions taken are transferring rights with cash or partial payments made on the agreement of each party (seller and buyer) attended by the Customary Chief / Village Head.

From the literature review, the real, cash and light understanding can be interpreted as follows: ${ }^{8}$

a) Real, means that the will that is spoken must be followed by real actions such as the money received by the seller and an agreement made before the Village Head.

b) Cash is the surrender of the rights by the seller to be carried out together with the payment by the buyer and immediately the rights have been transferred.

c) It is called light, if it is carried out in the presence of a Customary Chief or Village Head who acts as an official who bears the regularity and legitimacy of the act of transferring the rights (plus witnesses) so that the action is known to the public.

Based on the results of research in the field and interviews with Mr. Zaidun, he said, the legitimate sale and purchase of land without involving Land Deed Makers (PPAT) is legal, but the weakness of such legal actions cannot be registered with the National Land Agency office to change ownership data or transfer of title. ${ }^{9}$

Based on the results of the sale and purchase research conducted before the village head / village head, it is lawful, when fulfilled the material requirements mentioned above. Buying and selling in the

\footnotetext{
${ }^{6}$ http://digilib.unila.ac.id/9047/90/BAB\%20II.pdf, accessed on April 15, 2019, at 10:40

${ }^{7}$ Ibid, p.13-14

${ }^{8}$ Penelitian Socio Legal, Op.cit p. 5, access May 2, 2019

${ }^{9}$ Interview, Zaidun Kasi Pertanahan Pertanahan, (Bima, 28-03-2019).
} 
presence of the Head of Village / Lurah meets the real, cash, and bright conditions, meaning that it is not carried out clandestinely. But the land office will refuse to register.

\section{The First Registration Process for Requests for Ownership of Land Against Land whose Proof of Ownership Is Lost}

Government Regulation No. 24 of 1997 also mentions the definition of land registration, namely in Article 1 number 1 states that Land Registration is a series of activities carried out by the Government continuously, continuously and regularly, including data collection, processing, bookkeeping, and presenting and maintaining physical and data data juridical, in the form of maps and lists, concerning plots of land and units of flats, including the granting of letters of proof of their rights to plots of land that already have their rights and ownership rights to apartment units and certain rights that burden them.

Further to Government Regulation No. 24 of 1997 concerning Land Registration, namely in Article 1 number 9 gives an understanding of the First Land Registration as follows "First Land Registration is an activity of land registration carried out on objects of land registration that have not been registered based on Government Regulation Number 10 of 1961 concerning Land Registration or This Government Regulation."

According to Boedi Harsono land registration is a series of activities carried out by the State/Government continuously and regularly, in the form of gathering certain information or data regarding certain lands in certain areas, processing, storing and presenting them for the benefit of the people, in order to provide legal certainty in the field of land, including the issuance of proof of evidence and maintenance. ${ }^{10}$

An application for land registration includes an application for register new rights, old rights or measurements for certain needs can be submitted by the applicant himself or through PPAT.

In the case of land registration, many also register land without assistance from the Land Deed Making Officer (PPAT). Landowners can directly take care of registering their own land, for people who can spend a little time then land registration conducted directly by the community can be carried out easily. The convenience can be clearly known at the Land Office.

Minister of Agrarian Regulation No. 3 of 1997 Article 60 paragraph (3) and paragraph (4) concerning ownership there are three possibilities for verification tools, namely:

a. Complete written evidence: does not require additional other evidence;

b. The written evidence is partially absent: reinforced the statements of witnesses and / or statements concerned;

c. All written evidence is no longer there: replaced with witness statements and / or statements in question.

In this case the three evidentiary tools above will all be examined again through announcements, to give an opportunity to the parties concerned to object.

The Bima City Land Office has provided the required forms in the land registration application as a manifestation of increasing service to the community. The requirements referred to are as follows:

a) Letter of application addressed to the Head of the Bima City Land Office or also called Model A (signed by the applicant / proxy)

b) Statement of Mastery of Physical Land Affairs (Sporadic)

\footnotetext{
${ }^{10}$ A.P. Parlindungan, Pendaftaran Tanah Di Indonesia (Based on PP. No. 24/1997, it was completed with the Regulation of the Position of Land Deed PP. 37 of 1998), First print, (Bandung : CV.Mandar Maju, 1999), p.72.
} 
c) Certificate from the Village Head regarding physical control (Model B)

d) Copy of C Village (legalized by the Village Head)

e) Certificate of Land History signed by the Village Head

f) Minutes of testimony consisting of two witnesses from the Village and the Village Chief

g) Certificate of Ex-Property Ownership

h) Photocopy of Applicant's KTP legalized by the Kelurahan / Kepala Desa

i) Original proof of ownership of Girik land / Petuk C / Letter C which contains the Registration Number / Number of Benchmark, Class, Area of Land.

j) Proof of land ownership

k) If obtained from a grant / sale and purchase before 1997 attach a statement of grant / sale and purchase, if obtained after 1997 attach a Notary Deed

1) If obtained from inheritance, then attach a certificate of inheritance and a statement of inheritance.

m) Fill in the Field Registration Form 201 (Minutes of Investigation on the History of Land and Determination of Limits) which are filled in by the parties from the Village.

If the proof of ownership of the land as referred to above is incomplete or non-existent, proof of ownership of the land can be carried out with other evidence supplemented by the statement in question and reliable information from at least 2 (two) witnesses from the environment. the local who has no family relationship with the person concerned to the second degree both in vertical and horizontal relations, which states that the person concerned is the right owner of the land.

In the case of evidence regarding land ownership as referred to in paragraph (1) and (2) Article 23 PP No. 24 of 1997 does not exist, the application must be accompanied by:

a) A statement of the application stating the following matters:

1) That the applicant has mastered the land in question for 20 years or more in succession or has obtained the control from the party or other parties who have mastered it. So that the time of mastery of the applicant and its predecessor amounts to 20 years or more;

2) That the control of the land has been carried out in good faith;

3) That the control has never been contested and is therefore considered recognized and justified by the customary law community or village / kelurahan concerned;

4) That the land is now not in dispute;

5) That if the statement contains matters that are not in accordance with reality, the signatory is willing to be prosecuted in a criminal or civil trial for giving information/for false testimony given.

b) Information from the Village Head / Lurah and at least 2 (two) witnesses whose testimony can be trusted, because their function as local customary elders and / or residents who have long lived in the village / kelurahan where the land is concerned does not have a family relationship with the applicant up to the second degree both in vertical and horizontal kinship, which justifies what is stated by the applicant in the official statement.

In the process of applying for first-time registration of land ownership rights in the City of Bima for people who buy and sell under the hand, they must attach a complete identity and proof of purchase and purchase. There are some problems in the application for land registration, one of which is missing evidence of ownership of land rights. 
Mr. Ridwan H.M. Taher is located at Penaraga, owning land that has been controlled for approximately 20 consecutive years with a land area of 400m2 located in Monggonao Sub-District. Mr. Ridwan is one of the rights holders whose proof of ownership is lost.

For the smooth implementation of land registration to address the problems that occur in connection with the loss of the deed, the land office will still process the land registration application.

Based on interviews with Mrs. Wiwin Winarti, SPP Kasubsi Registration that "if someone has mastered the land for more than 20 years in a row then the land is his right, and for the problem of loss of property rights in submitting a registration application does not have to attach a statement missing from the police." 11

From the results of the interviews over the loss of proof of ownership the action must attach the BAP from the police. Many people do not understand the importance of proof of ownership of land rights. As a result, many people do not store it properly, so they are prone to loss or damage.

The implementation of the land registration process is relatively long. Sometimes when handling problems arise unexpected problems and can hamper the course of the land registration process. For the first application for registration, the proof of ownership is lost or unable to attach evidence of the basis of the right because the lost can be replaced with a statement of physical control over the land made by the landowner witnessed by two or more witnesses and justified by the Lurah.

\section{Conclusion}

The practice of buying and selling land carried out under the hands is not in accordance with Government Regulation Number 24 of 1997 concerning Land Registration, which requires that buying and selling be made with authentic deeds, not under the hands. Purchases of customary or unregistered land carried out in accordance with the provisions of customary law are carried out brightly and in cash in front of or known to the local Village Head/Lurah. But the process of buying and selling land under the hands of the Head of Village/Lurah and witnesses is legal. because the fulfillment of the legal conditions for buying and selling according to Law Number 5 of 1960 concerning the Basic Agrarian Regulations, namely material and formal requirements that are cash, light and real. In addition, the sale and purchase has fulfilled the terms of sale and purchase according to Article 1320, the terms of the agreement.

The first application for land registration in Bima City whose proof of ownership is lost in practice can still be registered if the landlord has taken control of his land for approximately twenty years in a row, without attaching a certificate of loss from the Police Station. People who register land rights are asked to fill out a form of statement of physical control over land (SPORADIK) made by the owner of the land which is witnessed by two or more witnesses and justified by the Head of the Village.

\section{Recommendation}

1. The community must increase self-awareness to register their land with the local BPN to obtain legal certainty over their land.

2. Public awareness in knowing Government Regulation No.24 of 1997 concerning Land Registration and land certification must be improved through the role of the National Land Agency and the Village Head in disseminating both officially and informally. So that the people in Bima City have proof of land ownership and land certificates as legal powers over land.

3. The need to conduct a socialization concerns the importance of land registration to areas that are deemed necessary to do so. This is expected to create legal awareness for the community so that they are willing to register their land that does not yet have a certificate. Attracting the public to register their land is very important to achieve the land registration process.

\footnotetext{
${ }^{11}$ Interview with Wiwin Winarti, Head of Subdivision of Bima City Land Registration, (Kota Bima, 28/3/2019)
} 
To the community to keep land documents in a safe place, because the documents are securities and out-of-date evidence for the management of land rights.

\section{References}

Books

Baiq Henni Paramita Rosandi. (2016). Akibat Hukum Jual Beli Hak Atas Tanah Yang Belum Didaftarkan. Universitas Mataram.

Juwana Hikmahanto. (2017). Hukum Tanah Nasional. Thafa Media Yogyakarta, Jakarta.

Parlindungan,A.P. (1999). Pendaftaran Tanah Di Indonesia (Berdasarkan PP.No24/1997 dilengkapi dengan Peraturan Jabatan Pembuat Akta Tanah PP. 37 Tahun 1998). First print. CV.Mandar Maju, Bandung.

Soeroso, R. (2011). Perjanjian Dibawah Tangan Pedoman Praktis Pembuatan Dan Aplikasi Hukum. Jakarta, Sinar Grafika.

Tehupeiory Aartje. (2012). Pentingnya Pendaftaran Tanah Di Indonesia. Raih Asa Sukses Penebar Swadaya Group, Jakarta.

Putro Dwi Widodo, Zuhairi Ahmad, Ariehta EleisonSembiring, Lubis Taruli Elizabeth, Salam Syukron, Penelitian Socio Legal, Perlindungan Hukum Bagi Pembeli Yang Beritikad Baik Dalam Pluralisme Jual Beli Tanah, hlm.5, acces May 2, 2019.

Rosandi Paramita Henni Baiq. (2016). Akibat Hukum Jual Beli Hak Atas Tanah Yang Belum Didaftarkan, Universitas Mataram.

Regulations

Indonesia. Law concerning Basic Agrarian Principles Regulations. Law Number 5 of 1960.

Indonesia. Government Regulation Number 24 of 1997 concerning Indonesian Land Registration.

Indonesia. Regulation of the Minister of Agrarian Affairs / Head of the National Land Agency Number 3 of 1997 concerning Provisions for the Implementation of Government Regulation Number 24 of 1997 concerning Land Registration.

\section{Copyrights}

Copyright for this article is retained by the author(s), with first publication rights granted to the journal. This is an open-access article distributed under the terms and conditions of the Creative Commons Attribution license (http://creativecommons.org/licenses/by/4.0/). 